\title{
How Corporate Governance protects Indonesian Companies From Financial Distress
}

\author{
Novin Lesmana ${ }^{1}$, , Cacik Rut Damayanti ${ }^{2}$ \\ 1,2 Department of Business Administration, Faculty of Administrative Science, Brawijaya University, Malang, \\ Indonesia \\ *E-mail: novinesmana@gmail.com
}

\begin{abstract}
This research aimed to determine the influence of corporate governance which is proxied by the Independent Board of Commissioners, Board of Directors, Institutional ownership, and Financial Performance which is proxied by Return on Assets (ROA), Current Ratio (CR), Debt Ratio (DR) on Financial Distress as measured by Z-score. The importance of implementing corporate governance and corporate financial performance will help predict financial distress in firm. This research is conducted in property, real estate and buiding construction sector listed in Indonesia Stock Exchange periods 2016-2018. The type of this reasearch is explanatory research, using a quantitative approach. This research was conducted on 17 samples of property, real estate and buiding construction companies listed in Indonesia Stock Exchange during the periods 2016-2018. Samples were obtained through purposive sampling method. The analysis technique is used multiple linier regression. The result shows that Return on Assets, Current Ratio, Debt Ratio variables have a significant influence on financial distress. Variables Independent Board of Commissioners, Board of Directors, Institutional Ownership did not partially have a significant influence on financial distress.
\end{abstract}

Keywords: Corporate Governance; Financial Performance; Financial Distress

\section{Introduction}

Corporate Governance (CG) plays an importance rule to protect companies from failure. In the beginning, the CG concept in Indonesia began with a financial crisis in 1997-1998 and the crisis impacted the rupiah which dropped almost $80 \%$ drastically, this was due to the weakness of the company in implementing corporate governance regulations (IFC, 2014). CG is a system that can be provided and control the company to improve the company and so that it can create added value for stakeholders (Sutedi, 2012). CG is needed by the firm so that the firm's goals can be directed and to help create a good relationship between principals and agents of the company. Therefore, it is believed that CG provides a significant contribution on reducing a conflict between principle and agent. Low conflict risk between both parties is potentially strengthen the companies business process that leads to the low risk of financial distress. However, there is no evidence whether CG will reduce the company's risk to face a financial distress.

In addition to the concept of CG there is other information that can be used to forecast financial difficulties, namely the financial statements mechanism which is one indicator that can be used to determine the situation of a firm. The result of financial statements can be used as information for policy and decision making for the firm (Widhiari \& Merkusiwati, 2015).

Therefore, to find out the condition of a company financial ratios which are reflected on the financial statements will be a vital tool to predict financial decline. This research used financial ratios of profitability, liquidity, and leverage.

The profitability ratio used to predict financial distress is Return on Assets (ROA). ROA shows the productivity of the company in producing profit from its assets, which is measured by comparing net income and total assets (Wirasedana \& Setiawan, 2020). A low return on assets can indicate financial difficulties. The liquidity ratio used to predict financial distress is current ratio (CR). The current ratio is a ratio that calculate a firms ability to pay short-term liabilities that are due (Kasmir, 2016). CR can be used as an indicator to predict financial distress because it measures the capability of a firm's short-term liquidity of a company by using the company's current 
assets with liabilities. The indicator used in the leverage ratio is the Debt Ratio (DR). DR is used to calculate the ratios of company debt, which is obtained from the ratio of total debt compared by total assets (Andre \& Taqwa, 2014). The use of large debt will cause the company to become entangled in high debt levels and it is difficult to pay off the obligations.

There have been many studies on the corporate governance and financial performance on financial distress. This research refers to research conducted by Helena (2018) and Jenny (2018). However, there are differences in determining the variables in this study where the research variables use the ROA and DR for financial indicators. The result of previous studies, it is concluded that corporate governance structures and financial performance have different result. Therefore, the researcher is interested in researching how corporate governance protects Indonesian companies from financial difficulties.

This research will analyze the sector of property, real estate, and building construction, listed in Indonesia Stock Exchange during the periods 2016-2018. The reason for choosing this sector because during the periods 2016-2018 there is a decline in demand. This is shown by the performance of real estate until 2018. In the first quarter of 2016 real estate performance cumulatively was above $4 \%$ (c-to-c), this figure showed that the performance of the real estate sector was stable. However, over time the growth rate in the real estate sector has declined, in the second quarter of 2018 cumulative real estate performance slowed by $3.17 \%$ (c-to-c), until the end of 2018 in the fourth quarter real performance estate still under $4 \%$ (c-to-c) this is due to the slow growth of demand for a lease of the office room, shopping center, and apartment (bps.go.id).

Figure 1 explained that the sector of property, real estate, and building construction at the end of 2018 had a trading volume that dropped dramatically with total of $-9.64 \%$. This number is lower compared to previous years wherein 2017 it was $-4.81 \%$ and in 2016 it was $18.17 \%$ (www.idx.co.id).
Therefore, it can be said that there has been a phenomenon that has caused a decline in demand in the sector of property, real estate, and building construction. If this situation does not change, companies in the that sector will potentially facing a financial distress.

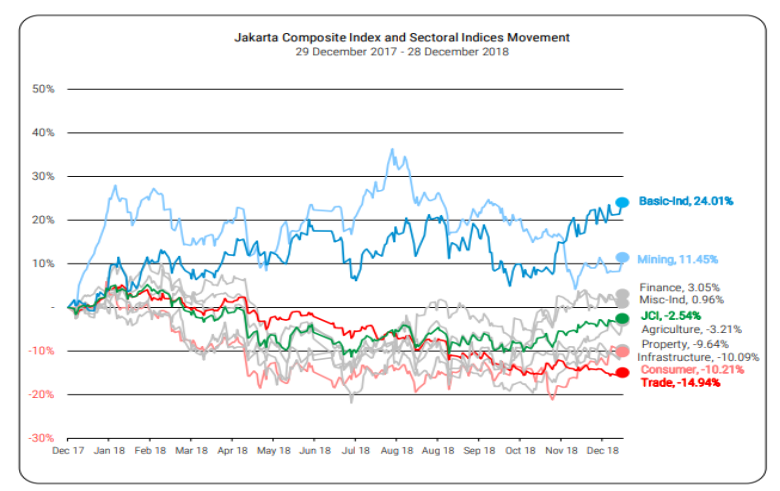

Figure 1. Jakarta Composite Index and Sectoral Indices Movements 2017-2018

Source: www.idx.co.id

The cause of this phenomenon in that sector is caused by several factors including the lack of CG management, poor financial reports, and a downward trend in property sales due to declining consumer demand. To minimize the indications of financial distress in a company steps are needed to minimize the occurrence of financial distress, companies can implement the concept of corporate governance and oversee the company's financial system by using analysis to prevent indications of financial distress. Besides the slowdown condition in property sector that this industry is facing a risk in financial distress, it is important to examine the internal condition of companies whether they having a strong $C G$ Financial Ratios (FR) to identify the company's condition if financial distress occurs early.

\section{Literature Review}

\section{Board of Independent Commissioners on Financial Distress}

Komite Nasional Kebijakan Governance (KNKG) (2006) stated that the Board of Commissioners consists of Commissioners who have no business and family relations with the controlling shareholder, members of the Board of Directors and other Commissioners, and with company. The duty of Independent Board of Commissioners has to supervise the 
policies made by the Directors. Based on existing agency theory, an independent board of commissioners can minimize the problems in agency theory or what is called (agency problem). The independent board of commissioners can provide independent oversight of the financial reporting process to minimize the possibility of financial statement manipulation, especially if supported by the active role of external auditors. Quality financial statements indicate the possibility of financial distress in a company. The total of Independent Commissioners in a company can also contribute to balance the result of the preparation of the company's financial statements.

Hanafi's research (2016) shows that the Independent Board of Commissioners variable has significant influence on financial distress. The percentage of independent board of commissioners has an influence on company activities which have an impact on the performance of a company. Based on previous theoretical studies and research, the hypothesis compiled is $\mathrm{H} 1$ : Independent Board of Commissioners has a negative significant influence on financial distress.

\section{Board of Directors on Financial Distress}

The board of directors has a duty responsible for managing the company to generate profits, the board of directors in a company is very important to determine the success of the company. According to Article 1 of Law No. 40 of 2007 concerning Limited Liability Companies stated that the Board of Directors is corporate organ that has the authority and responsibility in managing the company and also representing the company. Agency theory explains, regarding corporate governance can reduce conflicts that occur between owners and agents, and can reduce agency problems in a long period time which can lead to to potential financial distress. Research by Hanafi (2016), Harahap (2017), and Helena (2018) shows that the Board of Directors variable has significant influence on financial distress. The greater the number of boards of directors is likely to have an impact on the effectiveness of a firm's performance. The above description can be assumed as the following hypothesis. H2:
The Board of Directors has a negative significant influence on financial distress.

\section{Institutional Ownership on Financial Distress}

Hanifah (2013) stated that Institutional Ownership is a corporate governance mechanism that can minimize problems in agency theory between owners and agents until a meeting point emerge between company owners and managers. Based on agency theory between the owner and agent, the shareholder is responsible for overseeing the running of the company run by the agent. The large proportion of institutional ownership is more efficient in utilizing company assets so that the posibillty of financial difficulties can be reduced (Hanifah, 2013). The result of the research by Helena (2018) state that Institutional Ownership has significant influence on Financial Distress. Companies that have a large total institutional ownership will reduce the potential of financial distress. The portion of institutional ownership can be assumed based on theory and previous research is H3: Institutional ownership has a negative significant influence on financial distress.

\section{Return on Assets on Financial Distress}

The level of profitability is very important for companies to obtain profits for the company, because in general if the level of profit obtained is lower than the company's obligations then the indication of the company experiencing financial distress will occur. Profitability was measured using the indicator of ROA. ROA shows the productivity of the company in generating profit from its assets, which is measured by comparing net income and total assets (Wirasedana \& Setiawan, 2020).

Signaling theory is a form of signals delivered by companies to users of financial statements. Companies that have high profitability are assumed to be a good signal for the company's future opportunities which are then conveyed to investors. High profitability, can make investors want to invest in the companies, so the indication for the companies to experience financial distress is smaller. This has been proven by the result of Andre \& Taqwa's research (2014) which states that ROA has significant influence on financial distress. Higher ROA will reduce the 
company's risk of financial decline. Based on the theory and previous research, the hypothesis compiled is $\mathrm{H} 4$ : Return on Assets has a negative significant influence on financial distress.

\section{Current Ratio on Financial Distress}

One of the methods used to estimate financial distress is to analyze the company's ability to pay off short-term debt. One indicator used in knowing a company's liquidity is the current ratio (CR).

$\mathrm{CR}$ is a ratio that measures the capability of companies to pay off short-term debts that are due (Kasmir, 2016). Based on the signal theory if the current ratio is higher, it explains that the firm can pay off its short-term debts and that be a signal for the company, so investors can be interested in investing in the companies.Liquidity ratios can estimate financial distress, in a research by Jenny (2018) and Syaizamari (2019) which stated that the CR has significantly influences on Financial Distress. The hypothesis compiled based on the theory and previous research namely H5: Current Ratio has a negative significant influence on financial distress.

\section{Debt Ratio on Financial Distress}

The solvency ratio is the ratio to calculate the company's assets are financed with liabilities (Kasmir, 2016). Based on signaling theory, the form of a signal is information that a company conveys to users of financial statements. Long-term debt related to operational financing to debt that is past due is a signal for the company. Therefore, the higher the leverage level, the more difficult it is for the company to pay off its debts, even it will enlarge the company to experience financial distress. The indicator used in the leverage ratio is the Debt Ratio (DR). DR is a debt ratio used to set the ratio between total debt and total assets owned by a company (Kasmir, 2016). The result of the research by Andre and Taqwa (2014) stated that Debt Ratio has significant influence on Financial Distress. Based on previous theoretical and research studies, the hypothesis compiled is H6: Debt Ratio has a negative significant influence on financial distress.

Hypothesis:
H1: Independent Board of Commissioners has a negative significant influence on Financial Distress.

H2: Board of Directors has a negative significant influence on Financial Distress.

H3: Institutional Ownership has a negative significant influence on Financial Distress.

H4: Return on Assets (ROA) has a negative influence on Financial Distress.

H5: Current Ratio has a negative influence on Financial Distress.

H6: Debt Ratio has a negative influence on Financial Distress.

H7: Independent Board of Commissioners, Board of Directors, Institutional Ownership, Return on Assets (ROA), Current Ratio and Debt Ratio have a negative significant influence simultaneously on Financial Distress.

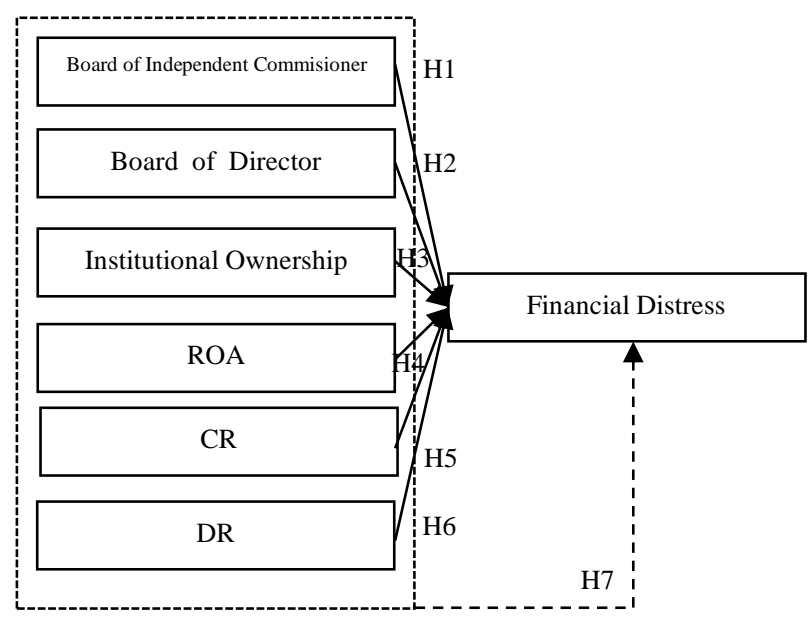

Figure 2. Research Hypotesis

\section{Method}

This research used a explanatory research type with quantitative approach. This research was conducted on the official website of the Indonesia Stock Exchange (IDX), which www.idx.co.id. The population in this research are property, real estate and building construction companies listed on the Indonesia Stock Exchange from 2016 to 2018. Based on the criteria set by the author, there is a sample of 17 companies from the list of companies in sector of the property, real estate, and building construction. From a total of 64 data for 3 years 
taken from the Indonesia Stock Exchange in the 2016 - 2018 period.

\section{Measurement Variables}

\section{Table 1. Measurement Variables}

\begin{tabular}{ll}
\multicolumn{1}{c}{ Variable } & \multicolumn{1}{c}{ Measurement } \\
$\begin{array}{l}\text { Board of } \\
\text { Independent } \\
\text { Commissioners }\end{array}$ & $\begin{array}{l}\text { Total Independent Commissioner } \\
\text { Total Commissioners }\end{array}$ \\
& Source: Hanafi (2016) $100 \%$ \\
\hline $\begin{array}{l}\text { Board of } \\
\text { Directors }\end{array}$ & $=\Sigma$ (Total board of directors) \\
Source: Hanafi (2016)
\end{tabular}

Source: Fahmi (2017)

\begin{tabular}{ll}
\hline Debt Ratio & $=\frac{\text { Total Liabilities }}{\text { Total assets }}$ \\
& Source: Fahmi (2017) \\
\hline Financial & $\mathrm{Z}_{2}=6,56 \mathrm{Z}_{1}+3,2 \mathrm{Z}_{2}+6,72 \mathrm{Z}_{3}+1,05$ \\
Distress & $\mathrm{Z}_{4}$ \\
$(\mathrm{Z}-$ Score $)$ & Source: Harahap (2017) \\
& Information: $\mathrm{Z}=$ bankruptcy index; \\
& $\mathrm{Z}_{1}=$ working capital / total assets; $\mathrm{Z}_{2}$ \\
& $=$ retained earnings / total assets; $\mathrm{Z}_{3}$ \\
& $=$ earning before interest and taxes / \\
& total assets; $\mathrm{Z} 4=$ book value of equity \\
& / book value of total debt
\end{tabular}

\section{Result and Discussion}

Table 2 shows the results of the Descriptive Statistics and R Square analysis.

Table 2. Descriptive Statistics

\begin{tabular}{lrrrrr}
\hline & N & \multicolumn{1}{c}{ Min } & \multicolumn{1}{l}{ Max } & Mean & \multicolumn{1}{c}{ Std. Dev } \\
\hline DKI & 51 & 25 & 50 & 37,6322 & 8,68229 \\
\hline DD & 51 & 2 & 8 & 4,33 & 1,519 \\
\hline IO & 51 & 32,36 & 99,71 & 72,8741 & 18,02137 \\
\hline ROA & 51 & $-9,24$ & 35,89 & 4,4075 & 7,29464 \\
\hline CR & 51 & 39,35 & 1276,86 & 268,1476 & 289,23816 \\
\hline DR & 51 & 4,15 & 78,73 & 32,8898 & 19,06922 \\
\hline FD & 51 & $-0,07$ & 28,34 & 6,1424 & 5,55025 \\
\hline $\begin{array}{l}\text { Valid N } \\
\text { (listwise) }\end{array}$ & 51 & & & & \\
\hline Note: DKT & & & & & \\
\hline
\end{tabular}

Note: DKI=Independent Board of Commissioners; $\mathrm{DD}=$ Board of Directors; $\mathrm{IO}=$ Institutional Ownership; ROA=Return on Asset; $\mathrm{CR}=$ Current Ratio; DR= Debt Ratio; FD= Financial Distress

Source: Output SPSS Ver. 23 (2020)

Table 3 shows the results of the Square analysis.
Table 3. Result of R Square

\begin{tabular}{cccr}
\hline Model & $\begin{array}{c}\mathrm{R} \\
\text { Square }\end{array}$ & $\begin{array}{c}\text { Adjusted } \\
\text { R Square }\end{array}$ & $\begin{array}{c}\text { Std. Error } \\
\text { of the Estimate }\end{array}$ \\
\hline 1 & 0,666 & 0,617 & 0,20283 \\
\hline Source: Output SPSS ver. $23(2020)$ \\
The Influence of & Independent & Variables on \\
Financial Distress Simultaneously
\end{tabular}

This research shows that the independent variables including the Independent Board of Commissioners, the Board of Directors, Institutional Ownership, Return on Assets (ROA), Current Ratio, and Debt Ratio simultaneously the independent variables contributed to determine the occurrence of financial distress. Significant influence was simultaneously shown in the $\mathrm{F}$ Test which showed significant result on financial distress (Table 4). This result is shown by the $f$ test which has a significant level of $0,000<0.05$.

Table 5: Result of F Test

\begin{tabular}{llrlll}
\hline \multicolumn{5}{c}{$\mathbf{A N O V A}^{\mathbf{a}}$} \\
\hline Model & $\begin{array}{l}\text { Sum of } \\
\text { Squares }\end{array}$ & df & $\begin{array}{c}\text { Mean } \\
\text { Square }\end{array}$ & F & Sig. \\
\hline Regression & 1200,926 & 6 & 200,154 & 25,953 &, $000 b$ \\
\hline Residual & 339,341 & 44 & 7,712 & & \\
\hline Total & 1540,266 & 50 & & & \\
\hline Dependent Variable : Financial Distress & \\
Source: Output SPSS ver. 23 (2020) &
\end{tabular}

The independent board of commissioners is expected to be able to conduct independent supervision related to company activities with professional and subjective preparation of financial statements to minimize the possibility of abuse of authority between owners and agents and can reduce indications of financial distress. The board of directors professionally runs the company well.

Institutional ownership can reduce problems in the agency because shareholders are responsible for overseeing the running of the company run by the agent. Return on assets (ROA) is expected to be able to improve the firm's profitability well to reduce indications of financial distress. The current ratio can provide a signal for companies so that investors can be interested in investing. Debt Ratio management of long-term debt properly will reduce the indication of financial distress.

Based on theoretical review, agency theory explained that the company management must be separated between the owner and the agent so that agency problems 
do not occur in the company's activities, by implementing a mechanism of corporate governance as a corporate organ, the company's performance can better to reduce indications of financial distress. A theoretical review of signaling theory explains that the company should give a good signal to stakeholders concerned related to reporting the company's financial performance. Therefore, by implementing corporate governance in a company will produce good financial performance and significantly influence financial distress.

The Influence of Independent Variables on Financial Distress Partially

Table 5. Result of Multiple Linear Regression

\begin{tabular}{crlrrr}
\hline \multicolumn{5}{c}{ Unstandardized } & \multicolumn{2}{l}{ Standardized } \\
\hline \multirow{2}{*}{ Model } & B & $\begin{array}{l}\text { Std. } \\
\text { Error }\end{array}$ & Beta & t & Sig. \\
\cline { 2 - 6 } & \multicolumn{7}{c}{ Coefficients } \\
\hline (Constant) & 7,402 & 3,438 & & 2.153 & 0,037 \\
\hline DKI & $-0,009$ & 0,054 & $-0,014$ & $-0,159$ & 0,874 \\
\hline DD & $-0,378$ & 0,316 & $-0,103$ & $-1,197$ & 0,238 \\
\hline KI & $-0,004$ & 0,023 & 0,014 & 0,194 & 0,847 \\
\hline ROA & 0,19 & 0,064 & 0,249 & 2,972 & 0,005 \\
\hline CR & 0,011 & 0,002 & 0,571 & 6,448 & 0 \\
\hline DR & $-0,103$ & 0,029 & $-0,355$ & $-3,505$ & 0,001 \\
\hline Depent
\end{tabular}

a. Dependent Variable: Financial Distress

Source: Output SPSS ver. 23 (2020)

\section{a. Independent Board of Commissioners}

The result shows that the t-test of independent board of commissioners has no significant influence on financial distress. The result of Independent Board of Commissioners in this research do not support the result of research conducted by Hanafi (2016) which shows an independent board of commissioners has a significant influence on financial distress, but this research supports the result of research conducted by Helena (2018) which shows an independent board of commissioners does not have a significant influence on financial distress. The result of this research also do not support agency theory which explains that an independent board of commissioners can reduce the occurrence of agency theory problems or so-called (agency problems) between owners and agents.

An independent board of commissioners is a board consisting of commissioners who are not from affiliated parties (KNKG, 2006).
The Indonesia Stock Exchange issued a regulation on the Decree of the Directors of the Jakarta Stock Exchange No. 315/BEJ/06/2000, which requires companies to have a board of commissioners of more than two people, of which $30 \%$ are independent commissioners. This research shows that the percentage of independent commissioners has no significant influence on financial distress. Referring to the Indonesian Stock Exchange regulations through the decision of the Board of Directors of the Jakarta Stock Exchange No. 315/BEJ/ $06 / 2000$, the result of the research found that several companies had a percentage of independent commissioners $<30 \%$ of independent board members. Descriptive data on the result of the research showed that there were 4 companies that had a percentage of independent commissioners below 30\%. The independent board of commissioners has to oversee the course of company activities related to the preparation of financial statements.

The average percentage of the independent board of commissioners $37.63 \%$ this indicates the percentage of the independent board of commissioners does not have an impact on the supervision of company activities related the preparation of company financial statement and does not have an impact that can reduce allegations of financial difficulties. Another reason is the lack of involvement of the independent board of commissioners which result in weak oversight of the company's activities. The existence of an independent board of commissioners has not been able to act properly as an effective supervisiory system to prevent companies from occurring financial distress (Helena, 2018).

\section{b. Board of Directors}

The result shows that the t-test of board of directors has no significant influence on financial distress. The result of board of directors in this research contradict the result of research conducted by Hanafi (2016), Harahap (2017), and Helena (2018) which shows that the board of directors has a significant influence on financial distress. This research does not support agency theory which explains about corporate governance can help reduce agency problems over a long period of the time that can cause the financial distress. 
According to article 1 of Law No. 40 of 2007 concerning limited liability companies explains the directorsare corporate organs that have authority and responsibility for the implementation of the company also representing the company. The size of the board of directors as recorded in the Financial Services Authority Regulation Number 33 / POJK.05 / 2014 is a minimum of two people. Based on the descriptive result proving that the sample company has implemented existing regulations with a minimum number of two people and has an average of four people.

This research shows that the average number of board of directors that is still minimal can reduce the effectiveness and efficiency in managing and managing a publicly listed company, this can lead to the possibility of financial distress. The smaller the number of boards of directors, will cause difficulties in organizing companies effectively and efficiently, because the division of tasks is not carried out properly, as well as the lack of resources in running the company which result in financial distress (Kristian, 2017).

\section{c. Institutional Ownership}

The result shows that the $t$-test of institutional ownership has no significant influence on financial distress. The result of institutional ownership in this research contradicts with the result of research conducted by Helena (2018) which shows institutional ownership has a significant influence on financial distress. However, this research supports the results of Harahap (2017) and Hanafi (2016) which shows that institutional ownership has no significant influence on financial distress. The result of this research does not support the theory of agency between the owner and agent, in which the shareholder is responsible for overseeing the running of the company run by the agent.

Institutional Ownership is a corporate governance mechanism that can minimize problems in agency theory between owners and agents until a meeting point emerge between company owners and managers (Hanifah, 2013). Institutional ownership is the percentage of voting rights in a company itself. The large proportion of institutional ownership is more efficient in utilizing company assets so that the potential of financial distress can be reduced (Hanifah, 2013).

This research shows that the average institutional ownership is $72.87 \%$. This indicates that the high and low percentage of institutional ownership in overseeing the running of the company does not guarantee the company can minimize the possibility of financial distress. That is because the supervision conducted by the company is ineffective then the indication of financial distress will be even greater. The higher institutional ownership, the financial condition will worsen, because corporate institutions cannot supervise company managers (Idarti \& Hasanah, 2018).

\section{d. Return on Assets (ROA)}

The result shows that the t-test of return on assets (ROA) has a significant influence on financial distress. The result of ROA in this research supports the result of research conducted by Andre \& Taqwa (2014) which shows that ROA has a significant influence on financial distress. The result of this research support the signaling theory that explains between companies and users of financial statements, that companies provide signals to users of financial statements for decision making related to the company's sustainability.

ROA shows the productivity of the company in generating profit from its assets, which is measured by comparing net income and total assets (Wirasedana \& Setiawan, 2020). The higher this ratio, the more it shows a good company performance in managing company assets in creating net income and reducing the indication of the possibility of financial distress. Judging from the average ROA in the sample companies shows a decrease in the amount each year. This shows the decline in the profitability of the company, whereas, the possibility of financial distress has increased. The decrease in ROA in the study sample is due to net profit in the study period is relatively small and is not proportional to the larger total assets each year. However, the company's management has tried to manage the company's assets well and this can be a signal for users of financial statements 
so that it will have an impact on the company's financial statements with maximum result and to be able to reduce the probability of financial distress.

\section{e. Current Ratio}

The result shows that the t-test of current ratio has a significant influence on financial distress. The result of $\mathrm{CR}$ in this research support the research conducted by Jenny (2018) and Syaizamari (2019) which shows that the Current Ratio has a significant influence on Financial Distress. This research supports the signaling theory which explains that the company gives a signal to users of financial statements for decision making related to the sustainability of the company and avoids the asymmetry of information in a company. Kasmir (2016) stated that the current ratio is a ratio that measures a firms ability to pay short-term obligations that are due. If a company has a high level of current ratio, it will be easy for the company to pay off its short-term debt when it is due (Pongrangga, 2015). From 2016 to 2018, the average current ratio of the sample companies was $268.15 \%$, where the company's management was able to manage current assets well and could pay off shortterm liabilities, this could give a signal to the company so that investors can be persuaded to invest in a company and with a good signal can reduce indications of financial distress.

\section{f. Debt Ratio}

The result shows that the t-test of debt ratio has a significant influence on financial distress. This research support the result of DR conducted by Andre \& Taqwa (2014) which shows that Debt Ratio has a significant influence on Financial Distress, while the result of this research support the signaling theory that shows the company should provide information to those who need it, one of which is investors as material for decision making towards the company.

Debt ratio is used to calculate the ratios of company debt, which is obtained from the ratio of total debt to total assets (Kasmir, 2016). Long-term debt related to operational financing to debt that is past due is a signal for the company. Therefore, if the level of long-term debt is getting higher, it will be increasingly difficult for companies to pay off their debts, and even will increase the company to experience financial distress.

The result shows that the level of debt ratio from 2016-2018 shows an increase in the average amount of long-term debt, this indicates that if the company continues to increase the level of long-term debt it will affect the company's finances that are difficult to pay their obligations and increase the occurrence of the company financial distress occurs. High debt can allow companies to violate debt agreements with creditors because the number of assets owned by the company cannot guarantee the debt owed by the company, as well as the burden of costs that are higher than total assets will cause the book value of the company's equity to be negative (Andre \& Taqwa, 2014). This can give a negative signal to shareholders if they want to invest in companies that have difficulty handling their long-term debt. Debt owed by the company, as well as the burden of costs that are higher than total assets will cause the book value company's equity to be negative (Andre $\&$ Taqwa, 2014). This can give a negative signal to shareholders if they want to invest in companies that have difficulty handling their long-term debt.

\section{Conclusions and Suggestions}

\section{Conclusions}

The result of the $F$ or simultaneous statistical tests show that the independent board of commissioners, board of directors, institutional ownership, return on assets (ROA), current ratio, and debt ratio have a significant positive influence simultaneously on financial distress.

The result of the $t$ or partial statistical test shows that the independent board of commissioners has no significant influence partially on financial distress. The reason for the insignificance of this variable is that the percentage of the independent board of commissioners does not affect the supervision of company activities related to the preparation of the company's financial statements and does not have the influence that it can minimize the allegation of financial distress

The result of the $t$ or partial statstical test shows that the independent board of commissioners has no significant influence 
partially on financial distress. The reason for the insignificance of this variable is that the percentage of the independent board of commissioners does not affect the supervision of company activities related to the preparation of the company's financial statements and does not have the effect that it can minimize the allegation of financial distress.

The result of the $t$ or partial statistical test shows that institutional ownership does not have a significant partial influence on financial distress. The reason for the insignificance of these variables is the percentage of institutional ownership in overseeing the running of the company does not guarantee the company can minimize the potentially of financial distress.

The result of $t$ the $t$ or partial statistical test shows that return on assets (ROA), current ratio and debt ratio have a partially significant influence on financial distress.

\section{Suggestion}

For the next researcher are expected to increase the number of samples and increase the number of study periods. This is meant by a larger population and getting a larger sample and is expected to represent the entire sector of companies listed on the Indonesia Stock Exchange.

For the next researcher are expected to classify companies in the beginning by using companies that have been declared bankrupt as legally bankrupt or experiencing financial distress.

The independent board of commissioners, the board of directors and institutional ownership in this research have not been able to significantly influence financial distress. Therefore, to get better research result in future studies can use other variables such as the board of commissioners, audit committee and managerial ownership to measure financial distress.

This research is expected to be able to provide an overview to investors regarding the condition of the company which is indicated to be experiencing financial distress, by taking into account various aspects of company performance. This research is also expected to provide the output about the company's financial performance in considering the occurrence of financial distress. Also, companies should be able to manage resources to obtain maximum profits and avoid the risk of bankruptcy.

\section{References}

Andre, O., \& Taqwa, S. (2014). Pengaruh Profitabilitas , Likuiditas, dan Leverage Dalam Memprediksi Financial Distress (Studi Empiris Pada Perusahaan Aneka Industri yang Terdaftar di BEI Tahun 2006-2010). Jurnal WRA. Vol.2, No.1 April 2014.

Fahmi, Irham. 2017. Analisis Laporan Keuangan. Bandung : Alfabeta. Jakarta: Mitra Wacana Media.

Hanafi, J., Breliastiti, R. (2016). Peran Mekanisme Good Corporate Governance dalam Mencegah Perusahaan Mengalami Financial Distress. Jurnal Online Insan Akuntan. 1 (1): 195-220.

Hanifah. (2013). Pengaruh Struktur Corporate Governance dan Financial Indicators Terhadap Kondisi Financial Distress (Studi Pada Perusahaan Manufaktur yang Terdaftar di Bursa. Diponegoro Journal of Accounting. Vol 2. No.2 : 1-15.

Harahap, Lili Wardani. 2017. Pengaruh Mekanisme Corporate Governance dan Firm Size Terhadap Kondisi Financial Distress Pada Perusahaan Property and Real Estate yang Terdaftar Di BEI Tahun 2010-2014. Jurnal Riset Akuntansi \& Bisnis. September 2017. Vol.17 No.2

Helena, Savera. (2018). Pengaruh Corporate Governance Terhadap Financial Distress (Studi Pada Perusahaan Transportasi yang Terdaftar di Bursa Efek Indonesia Periode 2013-2016). Jurnal Administrasi Bisnis (JAB), Vol.60 No.2 Juli 2018.

Idarti, I., \& Hasanah, A. (2018). Analisis Pengaruh Struktur Kepemilikan, Kebijakan Hutang dan Likuiditas Terhadap Financial Distress. Journal of Applied Managerial Accounting. 2(2), 160-178. 
Jenny, Satila Hasanah J. 2018. Pengaruh Struktur Kepemilikan dan Kinerja Keuangan Terhadap Financial Distress, Studi Pada Perusahaan Manufaktur yang Terdaftar di BEI Periode 20152016. Jurnal Ilmiah Mahasiswa Fakultas Ekonomi dan Bisnis. Vol.7 No.1 : 1-9.

International Finance Corporation (IFC) (2014). The Indonesia Corporate Governance Manual - First Edition. The Indonesia Corporate Governance Manual.

https://www.ojk.go.id/Files/box/the -indonesia-corporate-governancemanual-First-Edition.pdf. Diakses 28 Desember 2019.

Kasmir. (2016). Analisis Laporan Keuangan. Jakarta : Rajawali Pers.

Keputusan Direksi PT Bursa Efek Jakarta No: Ke-31/BEJ/06/2000 Tentang Ketentuan Umum Pencatatan Efek Bersifat Ekuitas Bursa. https://www.regulasip.id/electronicbook/11504. Diakses 17 Februari 2020.

Komite Nasional Kebijakan Corporate Governance (KNKG). (2006). Pedoman Umum GCG Indonesia 2006. https://ecgi.global/sites/default/files//co des/documents/indonesia_cg_2006_id. pdf. Diakses 28 November 2019.

Kristian, M. (2017). Pengaruh Jumlah Dewan Direksi dan Shareholder Equity to Total Asset Ratio Terhadap Financial Distress (Studi Pada Perusahaan Manufaktur yang Terdaftar Di BEI Tahun 2012-2015). Jurnal Ekonomi. 22 (3).

Peraturan Otoritas Jasa Keuangan Nomor 33/POJK.04/2014 Tentang Direksi and Dewan Komisaris Emiten atau Perusahaan Publik.
https://www.ojk.go.id/id/regulasi/Pages/P OJK-tentang-Direksi-dan-Dewan-Komisaris-Emiten-atau-PerusahaanPublik.aspx. Diakses 16 Maret 2020.

Pongrangga, R. A. 2015. Pengaruh Current Ratio, Total Asset Turnover dan Debt to Equity Ratio Terhadap Return On Equity (Studi Pada Perusahaan Sub Sektor Property dan Real Estate yang Terdaftar di BEI Periode 2011-2014). Jurnal Administrasi Bisnis, Vol 25 No 2.

Sutedi, A. (2012). Good Corporate Governance. Jakarta: Sinar Grafika. Jakarta: Sinar Grafika.

Syaizamari, Raden Achmad F. 2019. Peranan Rasio Keuangan Terhadap Kondisi Financial Distress Perusahaan Manufaktur Di Bursa Efek Indonesia (BEI). Jurnal Ilmiah Mahasiswa Fakultas Ekonomi dan Bisnis. Vol.7 No.2 : 1-23.

Undang-Undang Nomor 40 Tahun 2007 Tentang Perseroan Terbatas. https://www.ojk.go.id/sustainablefinance/id/peraturan/undangundang/Documents/5.\%20UU-402007\%20PERSEROAN\%20TERBAT AS.pdf. Diakses 17 Juni 2020.

Widhiari, N.L.M.A, \& Merkusiwati, N.K.L.A. (2015). Pengaruh Rasio Likuiditas, Leverage, Operating Capacity, Dan Sales Growth Terhadap Financial Distress. EJurnal Akuntansi Universitas Udayana. 11(2), 456-469.

Wirasedana, I., \& Setiawan, P. (2020). RasioRasio Keuangan Sebagai Prediktor Return Saham Pada Perusahaan Manufaktur Yang Terdaftar Di Bursa Efek Indonesia. E-Jurnal Akuntansi, 30(6), 1508 - 1521.

www.idx.co.id

www.bps.go.id 